\title{
Natrinema altunense sp. nov., an extremely halophilic archaeon isolated from a salt lake in Altun Mountain in Xinjiang, China
}

\author{
Correspondence \\ Pei-Jin Zhou \\ zhou@sun.im.ac.cn \\ Min Wu \\ wumin@cls.zju.edu.cn
}

\author{
Xue-Wei $\mathrm{Xu},{ }^{1,2}$ Pei-Gen Ren, ${ }^{2}$ Shuang-Jiang Liu, ${ }^{2}$ Min $\mathrm{Wu}^{1}$ \\ and Pei-Jin Zhou ${ }^{2}$ \\ ${ }^{1}$ College of Life Sciences, Zhejiang University, 38 Zheda Road, Hangzhou 310027, \\ P. R. China \\ ${ }^{2}$ Institute of Microbiology, Chinese Academy of Sciences, ZhongGuanCun, Haidian, Beijing \\ 100080, P. R. China
}

\begin{abstract}
A novel extremely halophilic strain, $\mathrm{AJ} 2^{\top}$, was isolated from Ayakekum salt lake located in the Altun Mountain National Nature Reserve in Xinjiang, China. This isolate was neutrophilic, motile and grew in a wide range of $\mathrm{MgCl}_{2}$ concentrations $(0.005-1.0 \mathrm{M})$. The major polar lipids of the isolate were $\mathrm{C}_{20} \mathrm{C}_{20}$ and $\mathrm{C}_{20} \mathrm{C}_{25}$ derivatives of phosphatidylglycerol, phosphatidylglycerol phosphate methyl ester and phosphatidylglycerol sulfate. A comprehensive 16S rRNA gene sequence analysis revealed that the isolate shared $96 \cdot 6-97 \cdot 7 \%$ sequence identity with Natrinema species. The isolate, however, could be genetically differentiated from these species by DNA-DNA hybridization analysis and on the basis of its physiological properties. On the basis of the polyphasic evidence, strain $\mathrm{AJ} 2^{\top}\left(=\mathrm{AS} 1.3731^{\top}=\mathrm{JCM} 12890^{\top}\right)$ represents the type strain of a novel species, for which the name Natrinema altunense sp. nov. is proposed.
\end{abstract}

On the basis of 16S rRNA gene sequences, salt tolerance and chemotaxonomic and physiological characteristics, the genus Natrinema was created in 1998 to accommodate Natrinema pellirubrum (formerly Halobacterium salinarum NCIMB 786) and Natrinema pallidum (formerly Halobacterium halobium NCIMB 777) (McGenity et al., 1998). In a phylogenetic tree based on 16S rRNA gene sequences, Natrinema species formed an independent cluster with respect to Halobacterium species. Natrinema species could be cultured at low salt concentrations, and possessed a specific protein profile and polar lipid composition. Sub sequently, a novel species of this genus, Natrinema versiforme, was described (Xin et al., 2000). Thus, to date there are three species in the genus Natrinema. In this study, we describe a novel extremely halophilic archaeon isolated from Ayakekum salt lake $\left(37^{\circ} 37^{\prime} \mathrm{N}, 89^{\circ} 29^{\prime} \mathrm{E} ; 3884 \mathrm{~m}\right.$ altitude) located in the Altun Mountain National Nature

Published online ahead of print on 14 January 2005 as DOI 10.1099/ ijs.0.63622-0.

The GenBank/EMBL/DDBJ accession number for the $16 \mathrm{~S}$ rRNA gene sequence of strain $\mathrm{AJ}^{\top}{ }^{\top}$ is $\mathrm{AY} 208972$.

Thin-layer chromatograms showing the lipid content of strain $\mathrm{AJ} 2^{\top}$ and other Natrinema species, along with a table of some characteristics distinguishing this strain from Natrinema versiforme AS $1.2365^{\top}$, are available as supplementary material in IJSEM Online.
Reserve in Xinjiang, China, and propose a novel species, Natrinema altunense sp. nov.

The low temperature, low nutrient levels, abundant sunlight and remote geographical location of Ayakekum salt lake make it a relatively isolated ecosystem. A water sample (approx. $400 \mathrm{ml}$ ) was collected from the edge of Ayakekum salt lake in summer. The $\mathrm{pH}$ of the water (determined using a $\mathrm{pH}$ meter) was slightly alkali, at approximately $\mathrm{pH} 7 \cdot 8$. The isolate was routinely grown aerobically at $37^{\circ} \mathrm{C}$ in rich medium (Oesterhelt \& Stoeckenius, 1974). Pure cultures were obtained by restreaking several times. The organism was grown and maintained on S-G medium (Sehgal \& Gibbons, 1960).

The phenotypic tests were performed according to the proposed minimal standards for the description of new taxon of the order Halobacteriales (Oren et al., 1997). The optimal conditions for growth were determined in S-G medium modified with $0 \cdot 85-5 \cdot 1 \mathrm{M} \mathrm{NaCl}$ or $0-1 \cdot 0 \mathrm{M} \mathrm{Mg}^{2+}$. To determine the $\mathrm{pH}$ required for growth (using increments of $0.5 \mathrm{pH}$ units, from $\mathrm{pH} 5.0$ to $\mathrm{pH} 9.5), 50 \mathrm{mM}$ MES

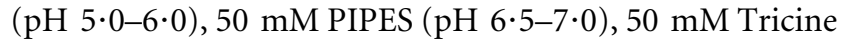
$(\mathrm{pH} 7 \cdot 5-8 \cdot 5)$ and $50 \mathrm{mM}$ CHES (pH 9.0-9.5) were employed as buffers. Cell morphology and motility were examined by using light microscopy (BX40; Olympus) and transmission electron microscopy (S-570; Hitachi). Gram staining was performed using samples fixed with acetic acid, 
as described by Dussault (1955). Anaerobic growth was tested in the presence of nitrate, L-arginine or DMSO (each at $5 \mathrm{~g} \mathrm{l}^{-1}$ ) in filled, stoppered tubes. Gelatin hydrolysis was determined as described by Oren et al. (2002). Hydrolysis of starch, casein and Tweens 20, 40 and 80, reduction of nitrate and nitrite, production of indole and $\mathrm{H}_{2} \mathrm{~S}$, activities of catalase and oxidase, and utilization of sugars, alcohols, amino acids and organic acids were tested according to Xin et al. (2000), as described by Oren et al. (1997).

Total lipids were extracted by using the modified method of Kamekura \& Kates (1988). Phospholipids and glycolipids were separated on silica-gel plates $(10 \times 10 \mathrm{~cm})$ by TLC and were analysed according to Xin et al. (2000). Genomic DNA was prepared by the method of Marmur (1961) and the purity was checked spectrometrically. The $\mathrm{G}+\mathrm{C}$ content of the DNA was determined by thermal denaturation $\left(T_{\mathrm{m}}\right)$ (Marmur \& Doty, 1962). The 16S rRNA gene sequence was amplified under conditions like those described by Gupta et al. (1983). The sequence was analysed along with sequences of closely related reference organisms from the FASTA network service. Sequence data were aligned with CLUSTAL W software, version 1.8 (Thompson et al., 1994). Phylogenetic trees were constructed by using neighbour-joining methods (Saitou \& Nei, 1987) with the MEGA 3 program package (Kumar et al., 2004). DNA-DNA hybridization was performed by using the thermal denaturation and renaturation method of De Ley et al. (1970) as modified by Huß et al. (1983).

The profile of the major polar lipids of strain $\mathrm{AJ}^{\mathrm{T}}$, comprising $\mathrm{C}_{20} \mathrm{C}_{20}$ and $\mathrm{C}_{20} \mathrm{C}_{25}$ derivatives of phosphatidylglycerol, phosphatidylglycerol phosphate methyl ester and phosphatidylglycerol sulfate, was similar to that of Natrinema species (see Supplementary Fig. A in IJSEM Online). In a phylogenetic tree based on 16S rRNA gene sequences (Fig. 1), strain $\mathrm{AJ}_{2}{ }^{\mathrm{T}}$ clustered with Natrinema species with validly published names. The results indicated that strain $\mathrm{AJ} 2{ }^{\mathrm{T}}$ belongs to the genus Natrinema.
Strain $\mathrm{AJ} 2^{\mathrm{T}}$, however, could be distinguished from Natrinema species with validly published names on the basis of some phenotypic characteristics (Table 1) (additional distinguishing characteristics are available in a Supplementary Table in IJSEM Online). Two-dimensional TLC revealed that strain $\mathrm{AJ} 2^{\mathrm{T}}$ possessed a major glycolipid, which ran very slowly. The glycolipid spot was also found in N. pellirubrum JCM $10476^{\mathrm{T}}$. The amount of this glycolipid in $\mathrm{AJ} 2^{\mathrm{T}}$ was observably less than that in N. pellirubrum JCM $10476^{\mathrm{T}}$, and the amount of phosphatidylglycerol sulfate in $\mathrm{AJ} 2^{\mathrm{T}}$ was more than that in $N$. pellirubrum JCM $10476^{\mathrm{T}}$ (McGenity et al., 1998). Moreover, strain $\mathrm{AJ} 2^{\mathrm{T}}$ did not contain glycolipids found in N. pallidum JCM $8980^{\mathrm{T}}$ and $N$. versiforme AS $1.2365^{\mathrm{T}}$. Therefore, the polar lipid profiles among Natrinema species also served to distinguish them (see Supplementary Fig. B in IJSEM Online). The 16S rRNA gene sequence similarities between strain $\mathrm{AJ} 2^{\mathrm{T}}$ and $N$. pallidum JCM $8980^{\mathrm{T}}, N$. pellirubrum JCM $10476^{\mathrm{T}}$ and $N$. versiforme AS $1.2365^{\mathrm{T}}$ were $97 \cdot 06,96 \cdot 64$ and $97 \cdot 71 \%$, respectively. Furthermore, the DNA-DNA relatedness values for strain $\mathrm{AJ} 2^{\mathrm{T}}$ with respect to $N$. pallidum $\mathrm{JCM}$ $8980^{\mathrm{T}}, N$. pellirubrum JCM $10476^{\mathrm{T}}$ and $N$. versiforme AS $1.2365^{\mathrm{T}}$ were $49 \cdot 3 \%(\mathrm{SD}=4 \cdot 3 \%), 35 \cdot 5 \%(\mathrm{SD}=2 \cdot 6 \%)$ and $51.4 \%(\mathrm{SD}=1.3 \%)$, respectively. The values were based on three independent determinations.

Overall, our data indicate that strain $\mathrm{AJ} 2^{\mathrm{T}}$ represents a novel species of the genus Natrinema, for which we propose the name Natrinema altunense sp. nov.

\section{Description of Natrinema altunense sp. nov.}

Natrinema altunense (al.tu.nen'se. N.L. neut. adj. altunense of Altun, referring to isolation of the organism from Altun Mountain, China).

Cells are rods that measure $0 \cdot 8-1 \cdot 2 \times 3-7 \mu \mathrm{m}$ and become pleomorphic under unfavourable conditions. Cells are motile and Gram-negative. Colonies are orange or red,

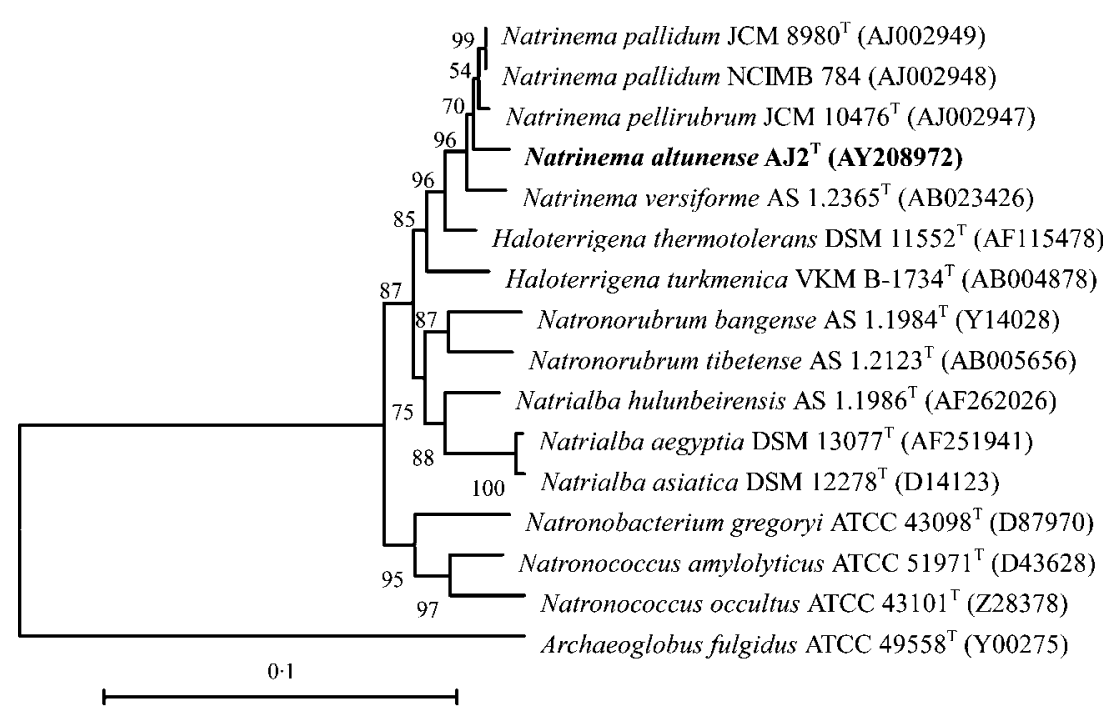

Fig. 1. Phylogenetic tree based on $16 \mathrm{~S}$ rRNA gene sequences from strain $\mathrm{AJ} 2^{\top}$ and other related organisms. The tree was constructed using the neighbour-joining method, with bootstrap values calculated from 1000 resamplings. The number at each branch point represents the percentage bootstrap support. Bar, 10 substitutions at any nucleotide position per 100 nucleotide positions. 
Table 1. Some characteristics that distinguish $N$. altunense sp. nov. from other Natrinema species

Taxa: 1, strain $\mathrm{AJ} 2^{\mathrm{T}}$; 2, N. versiforme AS $1.2365^{\mathrm{T}}$; 3, N. pellirubrum JCM $10476^{\mathrm{T}}$; 4, N. pallidum JCM $8980^{\mathrm{T}}$. Symbols: + , positive; - , negative; W, weak; NR, not reported.

\begin{tabular}{|c|c|c|c|c|}
\hline Characteristic & 1 & $2^{\star}$ & $3 \dagger$ & $4 \dagger$ \\
\hline $\mathrm{Mg}^{2+}$ range $(\mathrm{M})$ & $0 \cdot 005-1 \cdot 000$ & $0 \cdot 005-0 \cdot 500$ & NR & NR \\
\hline $\mathrm{pH}$ range & $6 \cdot 0-8 \cdot 0$ & $6 \cdot 0-8 \cdot 0$ & $6 \cdot 0-8 \cdot 6$ & $6 \cdot 0-8 \cdot 4$ \\
\hline pH optimum & $7 \cdot 0-7 \cdot 7$ & $6 \cdot 5-7 \cdot 0$ & $7 \cdot 2-7 \cdot 8$ & $7 \cdot 2-7 \cdot 6$ \\
\hline Anaerobic growth with nitrate & $\mathrm{W}$ & + & - & - \\
\hline \multicolumn{5}{|l|}{ Gas formation from: } \\
\hline Nitrate & + & + & - & - \\
\hline Nitrite & + & NR & - & NR \\
\hline $\mathrm{H}_{2} \mathrm{~S}$ formation & + (From thiosulfate $)$ & $+($ From sulfur $)$ & - (From cysteine) & - (From cysteine $)$ \\
\hline \multicolumn{5}{|l|}{ Utilization of: } \\
\hline Fructose & - & + & + & + \\
\hline Mannose & $\mathrm{W}$ & + & NR & NR \\
\hline Lactose & - & - & + & + \\
\hline Galactose & - & + & NR & NR \\
\hline D-Ribose & - & + & + & - \\
\hline Sucrose & - & + & NR & NR \\
\hline D-Xylose & - & + & NR & NR \\
\hline Glycolipid content & One major glycolipid $\ddagger$ & $\begin{array}{l}\text { One major } \\
\text { glycolipid }\end{array}$ & $\begin{array}{l}\text { One sulfated } \\
\text { glycolipid } \neq\end{array}$ & $\begin{array}{l}\text { Several unidentified } \\
\text { glycolipids }\end{array}$ \\
\hline
\end{tabular}

${ }^{\star}$ Data from Xin et al. (2000).

$\dagger$ Data from McGenity et al. (1998).

$\ddagger$ The glycolipid ran very slowly on TLC plates.

smooth, circular and elevated. Growth requires at least $1 \cdot 7 \mathrm{M} \mathrm{NaCl}$, optimally 3.0-4.3 M NaCl. Growth occurs at $0 \cdot 005-1 \mathrm{M} \mathrm{MgCl}_{2}$, optimally at around 0.05-0.2 $\mathrm{M} \mathrm{MgCl}_{2}$. The $\mathrm{pH}$ range for growth is $6 \cdot 0-8 \cdot 0$, with an optimum at pH 7:0-7·7. Chemo-organotrophic. Grows anaerobically in the presence of nitrate. Oxidase- and catalase-positive. Nitrate and nitrite are reduced, and gas is produced. Indole formation is negative. Starch and casein are not hydrolysed. Gelatin and Tweens 20, 40 and 80 are hydrolysed. $\mathrm{H}_{2} \mathrm{~S}$ is produced from thiosulfate. The following substrates are utilized for growth: glucose, glycerol, maltose, glutamate, alanine, arginine, lysine, ornithine, acetate, fumarate, malate, propionate, pyruvate and succinate. Acid is produced from glucose, glycerol, maltose and mannose. Sensitive to norfloxacin, but not to erythromycin, neomycin, ciprofloxacin, streptomycin, kanamycin, ampicillin or vancomycin. The major polar lipids are $\mathrm{C}_{20} \mathrm{C}_{20}$ and $\mathrm{C}_{20} \mathrm{C}_{25}$ derivatives of phosphatidylglycerol, phosphatidylglycerol phosphate methyl ester, phosphatidylglycerol sulfate and some unidentified glycolipids. The $\mathrm{G}+\mathrm{C}$ content of the DNA is $65.6 \mathrm{~mol} \%\left(T_{\mathrm{m}}\right)$.

The type strain, $\mathrm{AJ} 2^{\mathrm{T}}\left(=\mathrm{AS} 1.3731^{\mathrm{T}}=\mathrm{JCM} 12890^{\mathrm{T}}\right)$, was isolated from a salt lake in Altun Mountain in China.

\section{Acknowledgements}

We thank M. Zhi-Pei Liu, Bao-Jun Wang and Mrs Jie Feng for their help and comments. This work was partially supported by a grant from the National Natural Science Foundation of China (grant no. 30370029) and the Major State Basic Research Development Program of China (973 Program) (grant no. 2004cb719601).

\section{References}

De Ley, J., Cattoir, H. \& Reynaerts, A. (1970). The quantitative measurement of DNA hybridization from renaturation rates. Eur $J$ Biochem 12, 133-142. 
Dussault, H. P. (1955). An improved technique for staining red halophilic bacteria. J Bacteriol 70, 484-485.

Gupta, R., Lanter, J. M. \& Woese, C. R. (1983). Sequence of the $16 \mathrm{~S}$ ribosomal RNA from Halobacterium volcanii, an archaebacterium. Science 221, 656-659.

Huß, V. A. R., Festl, H. \& Schleifer, K. H. (1983). Studies on the spectrophotometric determination of DNA hybridization from renaturation rates. Syst Appl Microbiol 4, 184-192.

Kamekura, M. \& Kates, M. (1988). Lipids of halophilic archaebacteria. In Halophilic Bacteria II, pp. 25-54. Edited by F. RodriguezValera. Boca Raton, FL: CRC Press.

Kumar, S., Tamura, K. \& Nei, M. (2004). MEGA3: integrated software for Molecular Evolutionary Genetics Analysis and sequence alignment. Brief Bioinform 5, 150-163.

Marmur, J. (1961). A procedure for the isolation of deoxyribonucleic acid from microorganisms. J Mol Biol 3, 208-218.

Marmur, J. \& Doty, P. (1962). Determination of the base composition of deoxyribonucleic acid from its thermal denaturation temperature. J Mol Biol 5, 109-118.

McGenity, T. J., Gemmell, R. T. \& Grant, W. D. (1998). Proposal of a new halobacterial genus Natrinema gen. nov., with two species Natrinema pellirubrum nom. nov. and Natrinema pallidum nom. nov. Int J Syst Bacteriol 48, 1187-1196.
Oesterhelt, D. \& Stoeckenius, W. (1974). Isolation of the cell membrane of Halobacterium halobium and its fractionation into red and purple membrane. Methods Enzymol 31, 667-678.

Oren, A., Ventosa, A. \& Grant, W. D. (1997). Proposed minimal standards for description of new taxa in the order Halobacteriales. Int J Syst Bacteriol 47, 233-238.

Oren, A., Elevi, R., Watanabe, S., Ihara, K. \& Corcelli, A. (2002). Halomicrobium mukohataei gen. nov., comb. nov., and emended description of Halomicrobium mukohataei. Int J Syst Evol Microbiol 52, 1831-1835.

Saitou, N. \& Nei, M. (1987). The neighbor-joining method: a new method for reconstructing phylogenetic trees. Mol Biol Evol 4, 406-425.

Sehgal, S. N. \& Gibbons, N. E. (1960). Effect of metal ions on the growth of Halobacterium cutirubrum. Can J Microbiol 6, 165-169.

Thompson, J. D., Higgins, D. G. \& Gibson, T. J. (1994). CLUSTAL W: improving the sensitivity of progressive multiple sequence alignment through sequence weighting, position-specific gap penalties and weight matrix choice. Nucleic Acids Res 22, 4673-4680.

Xin, H., Itoh, T., Zhou, P., Suzuki, K., Kamekura, M. \& Nakase, T. (2000). Natrinema versiforme sp. nov., an extremely halophilic archaeon from Aibi salt lake, Xinjiang, China. Int J Syst Evol Microbiol 50, 1297-1303. 